\title{
A Decision Support System for Appointment of Teaching Staff Islamic Boarding School Using a Weighted Product Algorithm
}

\author{
Nur Lukman ${ }^{1}$, Deden Suparman ${ }^{2}$, Jati Gunawan ${ }^{3}$, Wildan Budiawan Zulfikar ${ }^{4}$, Rio Guntur Utomo ${ }^{5}$ \\ \{n.lukman@uinsgd.ac.id ${ }^{1}$,denrut70@yahoo.com², jati.gunawan96@gmail.com ${ }^{3}$, \\ wildan.b@uinsgd.ac.id ${ }^{4}$, rgu1n15@soton.ac.uk $\left.{ }^{5}\right\}$ \\ Universitas Islam Negeri Sunan Gunung Djati Bandung, Indonesia ${ }^{1234}$, University of \\ Southampton ${ }^{5}$
}

\begin{abstract}
Human resources are one of the important things at Al-Basyaryah Islamic Boarding School in order the school meets the national standards of Islamic boarding schools. However, the appointment of teaching staff in Al-Basyaryah Islamic boarding schools is still poorly managed. It is necessary to have a good process of teaching appointment for the school to be categorized as a good Islamic boarding school. Using information technology, the appointment of teaching staff in Islamic boarding schools can be facilitated by a decision support system that acts as a recommendation (proposal) to support the management decisions in the boarding school in planning the appointment of teaching staff. The purpose of this research is to facilitate the appointment of teaching staff in Islamic boarding schools as an agreement for the management of Islamic boarding schools to deal with complaints about the appointment of teaching staff. The decision support system for the appointment of teaching staff in Islamic boarding schools was developed by using a weighted product algorithm. This approach recommended teaching staff to be more effective than 30 teaching staff.
\end{abstract}

Keywords: Decision Support System, weighted product algorithm, Islamic Boarding School.

\section{Introduction}

In Indonesia, generally the status of employee is divided into two, there are permanent officers and there are the interim officers. The fundamental difference between these two types can usually be seen from the rights and obligations. Some institutions determine the permanent officers from the performance of the employee's devotion, the initial selection by recruiting process, or both. One of the institutions that the appointment of employees by considering the employee's devotion is the Islamic Boarding School Al-Basyariyah. This institution conducts the appointment of officers based on their devotion, whether staff or teachers. Teachers who have high loyalty to their devotion have the right to rapture or get promotion and can be used as an achievement of the teacher itself [1].

Islamic Boarding School Al-Basyariyah is one of the educational institutions in West Java consisting of Kindergarten (TK), Elementary School (SD), Junior High School (SMP), and Senior High School (SMA). With the number of 143 permanent lecturers: 143, 38 interim officers, 20 staff, 131 term of service and 3,838 students. Moreover, the teacher's performance 
assessment process is held at the end of the semester (odd-even). The assessment process includes the assessment of the teacher judging by the aspects of quality and loyalty. The result of this performance assessment will be the evaluation material to improve performance. Each teacher who is elected as the best performing teacher will be appointed as a permanent officer. For now, the performance assessment of the teacher is still not effective in general.

In the current era, technology is used almost in various fields. One of the technologies that is often used is decision-support technology. Decision support is a technology built to evaluate Opportunities or to resolve a problem [2][3]. There are a lot of methods that can be used for a decision support system, one of them is Weighted Product. Weighted Product (WP) is a method of decision support system that works based on the desired criteria and techniques to support the decision making the process from several alternative options available[4]-[9]. This study aim is to develop a decision support system of the teaching staff in Islamic Boarding School AlBasyariyah using WP algorithm.

\section{Methodology}

This research uses Weighted Product method in deciding which teachers deserve appointment. Furthermore, the development model used in this research is the prototype model. The reason is that this model is very attentive to input and client criticism in the development of the software. This resulting in a software that is expected to suit the needs and desires of the client. This model is usually used for clients who do not know the requirements of the project.

\subsection{Prototype Model of Software Development Life Cycle}

There are several phases in the prototype that can be applied in determining which teachers are entitled to a chance of promotion using the WP method. The prototype was developed and then tested, reviewed and approved by the client to obtain Perfect design for further coding [10].

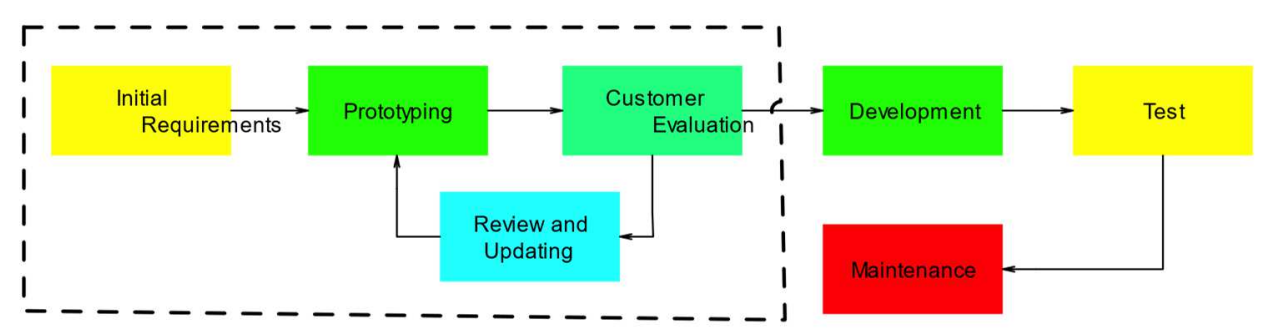

Fig. 1 Prototype Model [10]

\section{Initial Requirement}

The first step in the prototype method is to identify all devices and problems [10]. This phase is a very important phase because of all the needs of the decision support system were being identified by means of communication or a direct interview with the client. 


\section{Prototyping}

This phase, the prototype was being developed focusing on the needs of the system that has been obtained from the previous phase [10].

\section{Customer Evaluation}

The prototype in the previous phase was developed from the quick plan taken from the result of communication with the stakeholders in the Pondok Pesantren. There was a possibility if the developed prototype was not in accordance with the actual needs or there was a plan that had not yet implemented in the prototype. Hence, customer evaluation was carried out in this phase to evaluate the prototype in the previous phase [10].

\section{Review and Update}

After the evaluation of the customer, then the prototype was reviewed and then updated to comply with the evaluation.

\section{Development}

The prototype can be concluded as a final prototype when the review and update process was finished. The next step was the development of the decision support system of the teaching staff using the Weighted Product (WP) method as the final product.

\subsection{Weighted Product Method}

Weighted Product (WP) is one of the Multi-Attribute decision-making methods which uses several alternative options available in determining the decision[11][12][6]. The WP method uses multiplication to associate an attribute rating, where the rating of each attribute should be pre-identified with the corresponding attribute weights [11].

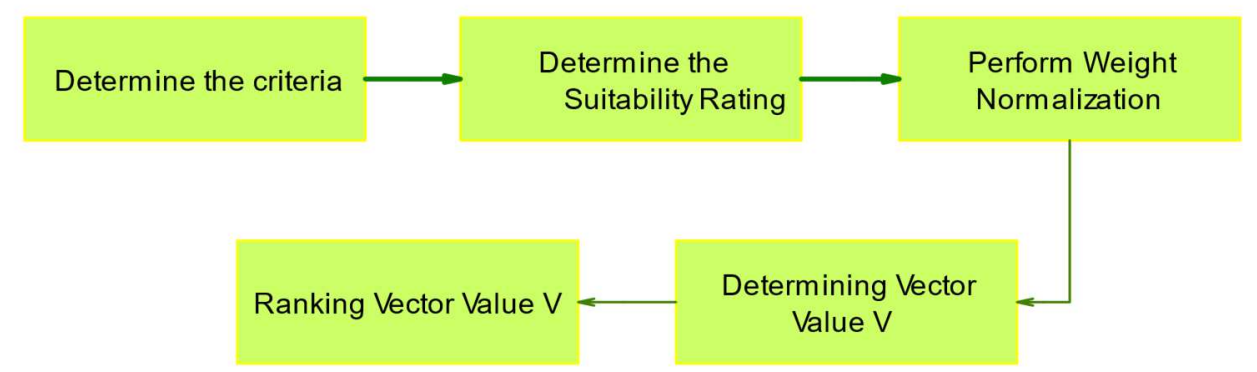

Fig. 2 Weighted Product Base Model[4]

Weighted Product method is calculated based on the importance level. The importance of method Weighted Product, namely[2]:

1. Not very important

2. Not important

3. Pretty Important 
4. Important

5. Very important

\section{Determine the Criteria}

Table 1. Comparison of Reliability of SUTTE, SMA, dan MACD

Table 1. Criteria and weights

\begin{tabular}{ll}
\hline CRITERIA & WEIGHT \\
\hline Loyalty & 25 \\
Quality & 20 \\
\hline
\end{tabular}

\section{Determine the Suitability Rating}

Any alternate match rating on each criterion

Table 2. Crips

\begin{tabular}{lll}
\hline CRITERIA & NAME OF CRIPS & VALUE \\
\hline Loyalty & Very bad & $0-5$ \\
& Bad & $6-25$ \\
& Enough & $26-50$ \\
& Good & $51-75$ \\
Quality & Excellent & $76-100$ \\
& Highly incapable & $0-5$ \\
& Unable to & $6-25$ \\
& Enough & $26-50$ \\
& Capable & $51-75$ \\
& Highly capable & $76-100$ \\
\hline
\end{tabular}

Table 3. Teaching Staff Appointment Data

\begin{tabular}{lll}
\hline ALTERNATE CODE & QUALITY & LOYALTY \\
\hline A1 & Enough & Capable \\
A2 & Excellent & Enough \\
A3 & Bad & Capable \\
A4 & Good & Highly capable \\
\hline
\end{tabular}

Table 4. Crips Value Data Teaching Staff

\begin{tabular}{lll}
\hline ALTERNATE CODE & $\mathrm{C} 1$ & $\mathrm{C} 2$ \\
\hline $\mathrm{A} 1$ & 50 & 75
\end{tabular}




\begin{tabular}{lll}
$\mathrm{A} 2$ & 100 & 50 \\
$\mathrm{~A} 3$ & 25 & 75 \\
$\mathrm{~A} 4$ & 75 & 100 \\
\hline
\end{tabular}

\section{Perform. Weight Normalization}

Normalization of criteria weights with the equation:

$$
W j=\frac{W j}{\sum W j}
$$

Where $W j$ are weights and $\sum W j$ is the sum of all weights

Table 5. Vector value $\mathrm{Wj}$

\begin{tabular}{lll}
\hline ALTERNATE CODE & C1 & C2 \\
\hline A1 & 0.4995 & 0.5 \\
A2 & 0.5015 & 0.4991 \\
A3 & 0.4985 & 0.5 \\
A4 & 0.5005 & 0.5009 \\
\hline
\end{tabular}

\section{4. $\quad$ Determining Vector Value $S_{i}$}

After determining the weight $\mathrm{W}$, the next step is to specify the vector value $\mathrm{S}_{\mathrm{i}}$. Where existing data is attached to the weights of each criterion. This calculation is intended to know the alternative value based on criteria using the formula below:

$$
S_{i} \prod_{j=1}^{n} X_{i j} W_{j}
$$

Where: $S_{i} \quad=$ Value of all alternatives

$X_{i j} \quad=$ Alternate value to-I against an alternate value to-j

$W_{j} \quad=$ The weighted value of each attribute

$\Pi \quad=$ Products

Table 6. Determining Vector ValueSi

\begin{tabular}{lll}
\hline ALTERNATE CODE & C1 & C2 \\
\hline A1 & 9.99012 & 12.49999 \\
A2 & 10.02953 & 12.47667 \\
A3 & 9.97042 & 12.49999 \\
A4 & 10.00983 & 12.52331 \\
\hline
\end{tabular}




\section{Determining Vector Value $V_{i}$}

Specify the value $V_{i}$ to find the best alternative value as result of selection, the $V_{I}$ value can be calculated with the following formula:

$$
V_{i}=\frac{\prod_{j}^{n}=1^{x i j^{w j k}}}{\prod_{j}^{n}\left(x_{j}\right) w_{j}}
$$

Where: $S_{i}=$ Value of all alternatives

$X_{i j} \quad=$ Alternate value to-I against an alternate value to-j

$W_{j} \quad=$ The weighted value of each attribute

$\Pi \quad=$ Products

Table 7. Vector Value Calculations Result Vi

\begin{tabular}{ll}
\hline ALTERNATE CODE & TOTAL \\
\hline A1 & 0.4 \\
A2 & 0.559 \\
A3 & 0.2685 \\
A4 & 0.75603 \\
\hline
\end{tabular}

6. Result Ranking Appointment of Teaching Staff

The final process is sorting the V1 values that have been obtained in the previous calculation process from the largest to the smallest:

Table 8. Sorting Results Teaching $\operatorname{Staff}\left(\mathrm{V}_{1}\right)$

\begin{tabular}{ll}
\hline ALTERNATE CODE & TOTAL \\
\hline A4 & 0.756 \\
A2 & 0.559 \\
A1 & 0.4 \\
A3 & 0.2685 \\
\hline
\end{tabular}

\section{Results and Discussions}

Research on the decision-making system of the teaching staff in Al-Basyariyah boarding School is a study of a process that has been implementing before, but still ineffective and inefficient in accordance with the data results. Therefore, the aim of the research is to conduct a study on a decision-support system in determining the decision of the teaching staff using Weighted Product method. From the research, the result shows that the Weighted Product method can be implemented into the decision supporting the teaching staff with the greatest alternative obtained by A4 with a value of 0756 . 
For the developed application, the number of teachers desired can be stated in advance and can be also specified. The result of the calculation shows the highest rating as much as the desired data.

\section{References}

[1] Fricles Ariwisanto Sianturi, "Implementasi Sistem Pendukung Keputusan Kenaikan Jabatan Guru Dengan Model Profile Matching Pada Sekolah Sma Swasta Raksana Medan," Mantik Penusa, vol. 18, no. 2, pp. 44-52, 2015.

[2] B. Ariebowo and R. Widayanti, "Sistem penunjang keputusan pemilihan bidang peminatan mahasiswa fakultas peternakan universitas brawijaya menggunakan metode weighted product," Senasif, no. September, pp. 655-664, 2017.

[3] M. Y. Cheng and A. F. V. Roy, "Evolutionary fuzzy decision model for cash flow prediction using time-dependent support vector machines," Int. J. Proj. Manag., 2011, doi: 10.1016/j.ijproman.2010.01.004.

[4] R. Fauzan, Y. Indrasary, and N. Muthia, "Sistem Pendukung Keputusan Penerimaan Beasiswa Bidik Misi di POLIBAN dengan Metode SAW Berbasis Web," J. Online Inform., vol. 2, no. 2, p. 79, 2018, doi: 10.15575/join.v2i2.101.

[5] I. Septiana, M. Irfan, A. R. Atmadja, and B. Subaeki, "Sistem Pendukung Keputusan Penentu Dosen Penguji Dan Pembimbing Tugas Akhir Menggunakan Fuzzy Multiple Attribute Decision Making dengan Simple Additive Weighting (Studi Kasus: Jurusan Teknik Informatika UIN SGD Bandung)," J. Online Inform., vol. 1, no. 1, p. 43, Jun. 2016, doi: 10.15575/join.v1i1.10.

[6] S. R. Arifin and J. C. Mintamanis, "Decision Support System for Determining Thesis Supervisor using A Weighted Product (WP) Method,” J. Online Inform., vol. 3, no. 2, p. 80, 2019, doi: 10.15575/join.v3i2.230.

[7] D. M. Khairina, D. Ivando, and S. Maharani, "Implementasi Metode Weighted Product Untuk Aplikasi Pemilihan Smartphone Android," J. INFOTEL - Inform. Telekomun. Elektron., vol. 8, no. 1, p. 16, May 2016, doi: 10.20895/infotel.v8i1.47.

[8] O. T. Kurahman et al., "The Implementation of Breadth First Search in Determining of Waris," in IOP Conference Series: Materials Science and Engineering, 2018, vol. 434, no. 1, doi: 10.1088/1757-899X/434/1/012033.

[9] D. M. Khairina, M. R. Asrian, and H. R. Hatta, "Decision support system for new employee recruitment using weighted product method," in Proceedings - 2016 3rd International Conference on Information Technology, Computer, and Electrical Engineering, ICITACEE 2016, 2017, doi: 10.1109/ICITACEE.2016.7892459.

[10] R. S. Presman, Software Engineering - A Practitioner's Approach, 8th ed., no. c. New York: McGraw-Hill Education, 2014.

[11] B. Nugroho, D. Remawati, and B. Widada, "IMPLEMENTASI METODE WP (WEIGHTED PRODUCT) UNTUK MENDUKUNG KEPUTUSAN PENJURUSAN SISWA DI SMA NEGERI 1 GROBOGAN,” J. Teknol. Inf. dan Komun., vol. 4, no. 2, Oct. 2016, doi: 10.30646/tikomsin.v4i2.277.

[12] D. M. Khairina, D. Ivando, and S. Maharani, "Implementasi Metode Weighted Product Untuk Aplikasi Pemilihan Smartphone Android," J. INFOTEL - Inform. Telekomun. Elektron., vol. 8, no. 1, p. 16, May 2016, doi: 10.20895/infotel.v8i1.47. 